\title{
ACCIDENTAL INFECTION BY Trypanosoma cruzi FOLLOW-UP BY THE POLYMERASE CHAIN REACTION: CASE REPORT
}

Andréa Tieko KINOSHITA-YANAgA(1), Max Jean de Ornelas TOLEDO(1), Silvana Marques de ARAÚJO(1), Berenice Pelizza VIER(2) \& Mônica Lúcia GOMES(1)

\begin{abstract}
SUMMARY
We report a case of accidental infection by Trypanosoma cruzi in a 42-year-old female patient who presented an inoculation chagoma. Laboratory confirmation was based on examination of fresh blood, Giemsa-stained blood smear, immunoenzyme test (EIA-IgG), indirect immunofluorescence (IIF-IgM, IgG) and polymerase chain reaction (PCR). Only the PCR gave a positive result, and the EIA test was inconclusive. Two treatments with benznidazole were necessary. PCR was the only technique that continued to give positive results for approximately two months ( 65 days, or 2.2 months) following the second treatment and negative results from 96 days ( 3.2 months) to 850 days ( 28.3 months). We concluded that the presence of an inoculation chagoma and use of PCR were important and decisive for diagnosis and follow-up of the case.
\end{abstract}

KEYWORDS: Trypanosoma cruzi; Laboratory accident; PCR; Diagnosis; Follow-up.

\section{INTRODUCTION}

Infections by Trypanosoma cruzi acquired in laboratory accidents have been previously reported ${ }^{7,9,13}$. Accidents with cutting or piercing instruments or from contact with mucosa during manipulation of material containing live parasites are high-risk. In such cases, etiological treatment must be administered with benznidazole at a dose of $7-10 \mathrm{mg} / \mathrm{kg}$ for ten days ${ }^{9}$. After accidental exposure to the parasite, the patient must be monitored clinically and through laboratory tests. Serological tests, hemoculture and xenodiagnosis are often used for diagnosis and followup of individuals receiving etiological treatment ${ }^{2,4}$. Early diagnosis of infections and better follow-up of etiological treatment are facilitated by laboratories where the polymerase chain reaction (PCR) technique $e^{2,6,8}$ is available. Here we report the diagnosis, etiological treatment, followup and laboratory confirmation of negativity of an accidental T. cruzi infection that occurred in a research laboratory in 2003, through autoinoculation of blood trypomastigote forms. The study was approved by the Permanent Committee on Ethics Involving Human Beings (Comitê Permanente de Ética em Pesquisa Envolvendo Seres Humanos, COPEP) of the State University of Maringá (UEM).

\section{CASE REPORT}

A 42-year-old female patient residing in Maringá, Paraná State, Brazil, sought medical attention at the UEM ambulatory clinic, complaining of low fever, fatigue, chronic headache, malaise and depression lasting approximately 21 days. When questioned about her profession, the patient reported that she had worked for more than 15 years as a technician in a laboratory performing research on Chagas' disease. During the examination, she related that three weeks previously she had been involved in a laboratory accident with auto-inoculation of trypomastigote forms of clone YP3 of T. cruzi strain Y, on the dorsal surface of the left hand at the base of the thumb, which she did not consider important at the time. Upon clinical examination, the patient was depressed, somewhat apathetic and afebrile. There was a discrete left-axillary ganglion swelling, and, near the inoculation site, a maculonodular, erythematose, consistent, slightly painful formation approximately $2.0 \mathrm{~cm}$ in diameter, which was identified by the clinic as a possible inoculation chagoma. Upon follow-up, the initial lesion slowly regressed with eventual desquamation (Fig. 1).

Following the initial clinical diagnosis, the patient returned to the Chagas' Disease Laboratory (Laboratório de Doença de Chagas, LDC) of the UEM and reported the accident. According to the security regulations established by the LDC, $15 \mathrm{~mL}$ of blood was collected for laboratory confirmation, and treatment was immediately initiated with benznidazole at a dose of $7 \mathrm{mg} / \mathrm{kg} /$ day for 15 days. The patient showed significant improvement in her symptoms three to four days after etiological treatment, which was considered to be a therapeutic diagnosis. Because the PCR remained positive, a second treatment ( $5 \mathrm{mg} / \mathrm{kg} /$ day for 30 days) according to the standard plan for cases of acute infection ${ }^{9}$ was initiated 23 days after the end of the first treatment. During the treatments, the patient reported symptoms possibly related to side effects of the medication, such as chronic headache, nausea, generalized discrete edema and a dry cough; nevertheless, the treatments were successfully concluded .

(1) Laboratório de Doença de Chagas, Departamento de Análises Clínicas, Universidade Estadual de Maringá, Maringá, PR, Brasil.

(2) Ambulatório Médico do Hospital Universitário de Maringá, Universidade Estadual de Maringá, Maringá, PR, Brasil.

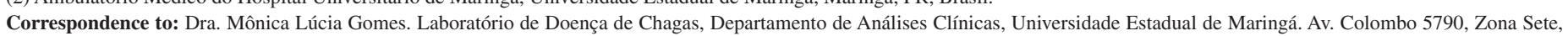
87020-900 Maringá, Paraná, Brasil. Tel.: +55 44 32618988; Fax: +55 44 3261-4860. E-mail: mlgomes@uem.br 


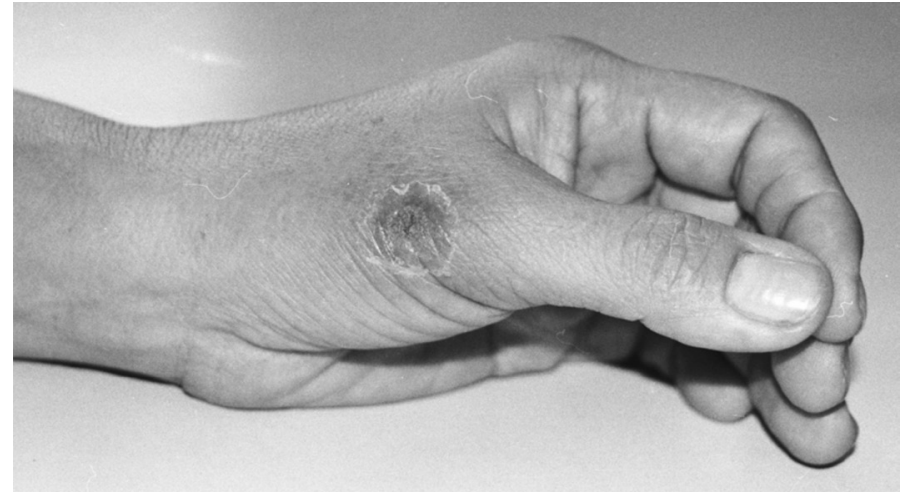

Fig. 1 - Inoculation chagoma on the dorsal surface of the left hand at the base of the thumb, 21 days after accidental inoculation with blood trypomastigote forms of Trypanosoma cruzi in a 42-year-old female patient.

In laboratory confirmation by direct examination of fresh blood, the stained blood smear and the indirect immunofluorescence (IIF - IgM and IgG - bioMérieux, Brazil) were negative, the enzyme immunoassay (EIA - IgG, Chagatest ${ }^{\circledR}$, Wiener, Argentina) gave an inconclusive result $(\mathrm{DO}=0.385$; Cut-off $=0.347)$ and the $\mathrm{PCR}^{5}$ using the primers 121 (5'AAATAATGTACGGG(T/G)GAGATGCATGA3') and 122 (5'GG TTCGATTGGGGTTGGTGTAATATA3') was positive. Eighteen days after the first treatment and at different times after the second treatment, the serological tests were negative. The only test that allowed us to follow this case precisely was the PCR, as can be observed in Fig. 2. The PCR remained positive for 36 to 65 days after the second treatment (lanes 6 and 7), but the intensity of the 330 bp band was visibly less than that observed post-infection (lane 4) and 18 days after the first treatment (lane 5). The lower intensity of the $330 \mathrm{bp}$ band may indicate a gradual decrease in the number of circulating parasites, because from 96 days or 3.2 months to 850 days or 28.3 months, this technique gave consistently negative results (lanes 8 to 11 ). Data regarding the dates of infection, treatments and results of IIF, EIA and PCR are summarized in the Table 1.

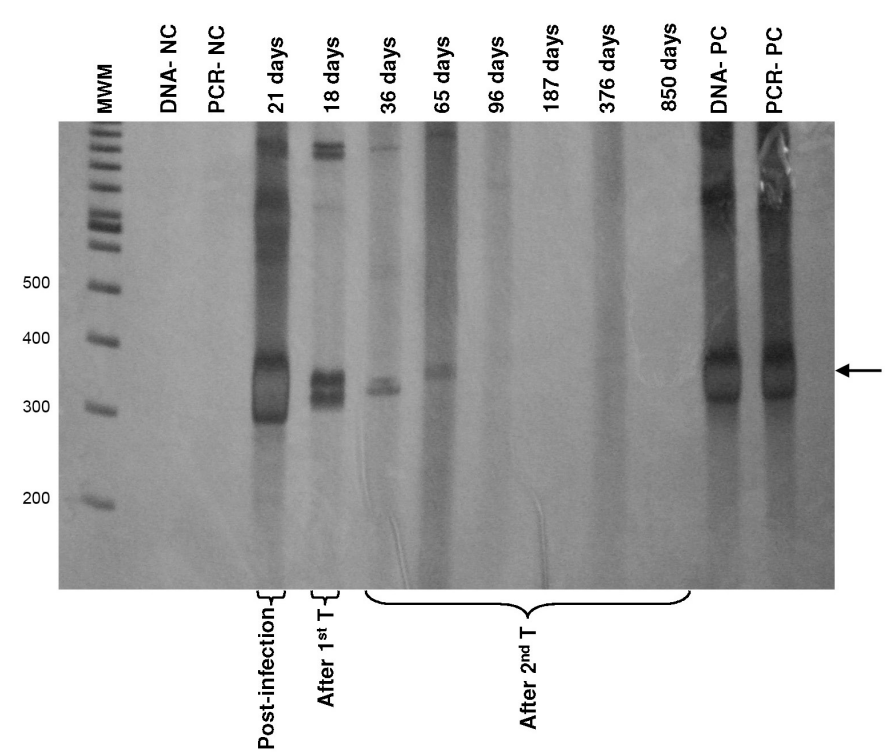

Fig. 2 - 4\% polyacrylamide gel showing specific 330 bp products (indicated by arrow) of the Trypanosoma cruzi kDNA minicircle in the blood of the accidentally infected patient. MWM = Molecular Weight Marker 100 bp DNA ladder (Invitrogen); DNA-NC = Negative Control of DNA extraction; PCR-NC = Negative Control of PCR; DNA-PC = Positive Control of DNA extraction; PCR-PC $=$ Positive Control of PCR; $\mathrm{T}=$ Treatment.

Table 1

Results of the tests: indirect immunofluorescence (IIF - IgM and IgG), enzyme immunoassay (EIA) and polymerase chain reaction (PCR) of a case of accidental infection by Trypanosoma cruzi in Maringá, Paraná, Brazi

\begin{tabular}{|c|c|c|c|c|c|c|c|c|}
\hline Date & $\begin{array}{l}\text { Days after } \\
\text { infection }\end{array}$ & Treatment & $\begin{array}{l}\text { Days (months) } \\
\text { post-treatment }\end{array}$ & Blood sample & EIA -IgG & IIF-IgM & IIF-IgG & PCR \\
\hline 02/10/2003 & 0 & & & ND & & & & \\
\hline $23 / 10 / 2003$ & 21 & First & Beginning & $\mathrm{D}$ & I & - & - & + \\
\hline $06 / 11 / 2003$ & 35 & & End & ND & & & & \\
\hline $24 / 11 / 2003$ & 53 & & $18(<1)$ & $\mathrm{D}$ & ND & ND & - & + \\
\hline $29 / 11 / 2003$ & 58 & Second & Beginning & ND & & & & \\
\hline $28 / 12 / 2003$ & 88 & & End & ND & & & & \\
\hline $02 / 02 / 2004$ & 124 & & $36(1.2)$ & $\mathrm{D}$ & - & ND & - & + \\
\hline 02/03/2004 & 153 & & $65(2.2)$ & $\mathrm{D}$ & - & ND & - & + \\
\hline $02 / 04 / 2004$ & 184 & & $96(3.2)$ & $\mathrm{D}$ & - & ND & ND & - \\
\hline 02/07/2004 & 275 & & $187(6.2)$ & $\mathrm{D}$ & - & ND & - & - \\
\hline 07/01/2005 & 464 & & $376(12.5)$ & $\mathrm{D}$ & ND & ND & - & - \\
\hline $21 / 03 / 2006$ & 1412 & & $850(28.3)$ & $\mathrm{D}$ & ND & ND & - & - \\
\hline
\end{tabular}

$\mathrm{ND}=$ Not done; $\mathrm{D}=$ Done; $\mathrm{I}=$ Inconclusive $($ Do $=0.385$ and Cut-off $=0.347) ;(-)=$ not reactive or negative; $(+)=$ positive. 


\section{DISCUSSION}

Although the patient was an experienced technician in a Chagas' disease research laboratory and knowledgeable about the parasite and the necessary safety precautions, she did not relate the clinical signs and symptoms to a possible $T$. cruzi infection. This association was only made at the time of the medical consultation. This report can serve as one more alert to professionals who work with this parasite. This case also reinforces the importance of the history as a diagnostic aid, since the presence of nonspecific symptoms may indicate a serious infection acquired in a work accident, as in the present case, in which the victim assumed that serious consequences would not occur.

Laboratory confirmation of the infection was obtained from the positive PCR results. Other tests used were not capable of diagnosing the infection, because the results were negative or inconclusive. Several workers have shown that in most cases the results of serological tests concord with those of the $\mathrm{PCR}^{2,3,6}$, but discordant results of a positive PCR with negative or inconclusive serological tests have also been reported ${ }^{2,6,10}$. Some of these workers ${ }^{2}$ did not exclude the possibility that serologically negative individuals with an active $T$. cruzi infection detected only by PCR may be more common than is presently supposed.

Beside the fresh-blood examination and the Giemsa-stained blood smear, no other parasitological test was done to diagnose this infection. Although hemoculture is available in our laboratory, this was not used because the laboratory is equipped to execute the PCR. This technique is more sensitive than hemoculture and xenodiagnosis in detecting the presence of $T$. cruzi $^{2,3,4,6,14}$. Furthermore, hemoculture shows low sensitivity, and requires a long time to process and obtain the results, and a large volume of blood ${ }^{2}$.

Of the alternative tests, PCR best allowed us to follow this case. We included a control for contamination, assessed the presence of reaction inhibitors, and also included negative and positive controls as described by GOMES et al. ${ }^{5}$. This technique was decisive in indicating the need for a second course of treatment, since the first treatment was ineffective. This probably occurred because the first treatment was administered considering the case as an accidental infection rather than an established acute infection, because of the strong impact of the patient's own report and because details of her symptoms were not available at first, only the presence of an inoculation chagoma. The PCR remained positive for 36 to 65 days after the second treatment with amplified product $(330 \mathrm{bp})$, at a lower intensity than that observed soon after the infection and 18 days after the first treatment. After this result, it remained negative from 3.2 to 28.3 months after treatment. These data indicate that the number of circulating parasites gradually decreased, as reported by MEIRA et al. ${ }^{8}$, that the treatment was effective, and that with the PCR it was possible to verify that the parasite had been eliminated. Many reports have shown the high sensitivity of PCR in detecting T. cruzi DNA in the blood of animals and of etiologically treated patients ${ }^{8,11}$, indicating therapeutic failure or a cure upon follow-up. RIERA et al. ${ }^{14}$ also emphasized the importance of using PCR in cases of congenital transmission, to monitor the parasitemia in neonates after etiological treatment.

Medical expertise, the presence of an inoculation chagoma and PCR were important for reaching a correct diagnosis. For follow-up after etiological treatment, the PCR was decisive in indicating the need for a second course of treatment. The conduct, the follow-up procedure, and the demonstration of negativity positively impacted the patient's behavior, emotional state, and continuity of life. This outcome fully meets the aims of the LDC, which is to improve the care of patients infected with $T$. cruzi $^{1,12}$

\section{RESUMO}

\section{Infecção acidental pelo Trypanosoma cruzi acompanhada pela reação em cadeia da polimerase: relato de caso}

Reportamos caso de infecção acidental pelo Trypanosoma cruzi em paciente do gênero feminino, 42 anos, que apresentou chagoma de inoculação. A confirmação laboratorial foi realizada pelo exame de sangue a fresco, esfregaço corado com Giemsa, imunoenzimaensaio (ELISA-IgG), imunofluorescência indireta (IFI-IgM, IgG) e reação em cadeia da polimerase (PCR). Somente a PCR foi positiva e a ELISA foi inconclusiva. Dois tratamentos com benznidazol foram necessários. PCR foi a única técnica que permaneceu positiva por aproximadamente dois meses (65 dias ou 2,2 meses) após o segundo tratamento e negativa de 96 dias (3,2 meses) a 850 dias (28,3 meses). Concluimos que a presença do chagoma de inoculação e o uso da PCR foram importantes e decisivos para o diagnóstico e o acompanhamento do caso.

\section{ACKNOWLEDGEMENTS}

This study was supported by Araucária Foundation (Fundação Araucária) - Support for Scientific and Technology Development of Paraná - Research Program for the SUS (PPSUS): Managing Shared Health 2006/2007 - Project Grant Agreement 191/2007, protocol 11,464.

\section{REFERENCES}

1.ARAÚJO, S.M.; ANDÓ, M.H.; CASSAROTTI, D.J. et al. - Programa ACHEI: atenção ao chagásico com educação integral no município de Maringá e região noroeste do Paraná, Brasil. Rev. Soc. bras. Med. trop., 33: 565-572, 2000.

2. CASTRO, A.M.; LUQUETTI, A.O.; RASSI, A. et al. - Blood culture and polymerase chain reaction for the diagnosis of the chronic phase of human infection with Trypanosoma cruzi. Parasit. Res., 88: 894-900, 2002.

3. CORONADO, X.; ZULANTAY, I.; REYES, E. et al. - Comparison of Trypanosoma cruzi detection by PCR in blood and dejections of Triatoma infestans fed on patients with chronic Chagas disease. Acta tropica, 98: 314-317, 2006.

4. GALVÃO, L.M.C.; CHIARI, E.; MACEDO, A.M. et al. - PCR assay for monitoring Trypanosoma cruzi parasitemia in childhood after specific chemotherapy. J. clin. Microbiol., 41: 5066-5070, 2003.

5. GOMES, M.L.; MACEDO, A.M.; VAGO, A.R. et al. - Trypanosoma cruzi: optimization of polymerase chain reaction for detection in human blood. Exp. Parasit., 88: 28-33, 1998.

6. GOMES, M.L.; GALVÃO, L.M.C.; MACEDO, A.M.; PENA, S.D.J. \& CHIARI, E. Chagas' disease diagnosis: comparative analysis among parasitologic, molecular and serologic methods. Amer. J. trop. Med. Hyg., 60: 205-210, 1999.

7. HERWALDT, B.L. - Laboratory-acquired parasitic infections from accidental exposures. Clin. Microbiol. Rev., 14: 659-688, 2001.

8. MEIRA, W.S.F.; GALVÃO, L.M.C.; MONTIJO, E.D. et al. - Use of the Trypanosoma cruzi recombinant complement regulatory protein to evaluate therapeutic efficacy following treatment of chronic chagasic patients. J. clin. Microbiol., 42: 707-712, 2004. 
KINOSHITA-YANAGA, A.T.; TOLEDO, M.J.O.; ARAÚJO, S.M.; VIER, B.P. \& GOMES, M.L. - Accidental infection by Trypanosoma cruzi follow-up by the polymerase chain reaction: case report. Rev. Inst. Med. trop. S. Paulo, 51(5): 295-298, 2009.

9. MINISTÉRIO DA SAÚDE. SECRETARIA DE VIGILÂNCIA EM SAÚDE. - Consenso brasileiro em Doença de Chagas, Uberaba, MG. Rev. Soc. bras. Med. trop., 38 (supl. 3): $1-29,2005$

10. MIYAMOTO, C.T.; GOMES, M.L.; MARANGON, A.V. et al. - Trypanosoma cruzi: sensitivity of the polymerase chain reaction for detecting the parasite in the blood of mice infected with different clonal genotypes. Exp. Parasit., 112: 198-201, 2006.

11. MIYAMOTO, C.T.; GOMES, M.L.; MARANGON, A.V. et al. - Usefulness of the polymerase chain reaction for monitoring cure of mice infected with different Trypanosoma cruzi clonal genotypes following treatment with benznidazole. Exp. Parasit., 120: 45-49, 2008.
12. MOTA, D.C.G.A.; PEREIRA, A.M.T.B.; GOMES, M.L. \& ARAÚJO, S.M. - Estresse e resiliência em Doença de Chagas. Aletheia, 24: 57-68, 2006.

13. PRATA, A. - Clinical and epidemiological aspects of Chagas disease. Lancet infect. Dis., 1: 92-100, 2001.

14. RIERA, C.; GUARRO, A.; EL KASSAB, H. et al. - Congenital transmission of Trypanosoma cruzi in Europe (Spain): a case report. Amer. J. trop. Med. Hyg., 75: 1078-1081, 2006.

Received: 27 February 2009

Accepted: 20 July 2009 